\title{
P-124
}

\section{Antimicrobial and Antityrosinase Activities of Isolated Compounds from Stem Bark of Bauhinia Rufescens (Fabaceae)}

\author{
Aminu Muhammad* and Hasnah Mohd Sirat \\ Department of Chemistry, Faculty of Science,Universiti Teknologi Malaysia81310 Skudai, Johor Bahru; \\ E-mail: muhdaminu@yahoo.com
}

A phytochemical investigation into the stem bark of Bauhinia rufescens (Fabaceae) has resulted in the isolation of $\alpha$-amyrin acetate, sitosterol 3-O- $\beta$-D-xylopyranoside, menisdaurin, sequoyitol and linoleic acid. Their structures were determined using spectroscopic data as well as comparison with literature data. The antimicrobial assay has been tested against Gram positive, Gram negative bacteria and fungal strains, while the tyrosinase inhibition assay was examined using L-Dopa as a substrate of tyrosinase enzyme. $\alpha$-amyrin acetate, sitosterol 3-O- $\beta$-D-xylopyranoside, menisdaurin and sequoyitol showed minimum inhibition concentration (MIC) values in the range of $900-450 \mu \mathrm{g} / \mathrm{mL}$ against all bacterial strains, while the MIC values for the fungal strains were recorded in the range of $450-112 \mu \mathrm{g} / \mathrm{mL}$. In the tyrosinase inhibition assay, $\alpha$-amyrin acetate was found to be moderately active against tyrosinase enzyme with an inhibition of $62.0 \%$ lower than the positive control, kojic acid (85.0\%).

Keywords: Phytochemistry, antimicrobial, antityrosinase, Bauhinia rufescens. 